\title{
GAMBARAN TINGKAT INFEKSI CACING SOIL TRANSMITTED HELMINTH (STH) PADA PENGRAJIN GERABAH DI DESA BANYUMULEK LOMBOK BARAT
}

\author{
Fahril Rizal Saputra ${ }^{1}$, Ida Bagus Rai Wiadnya ${ }^{2}$, Zainal Fikri ${ }^{3}$ \\ 1-3 Jurusan Analis Kesehatan, Poltekkes Kemenkes Mataram, Indonesia.
}

\begin{tabular}{l}
\hline \hline Article Info \\
\hline Article history: \\
Received Apr $25^{\text {th }}, 2019$ \\
Revised Mei $08^{\text {th }}, 2019$ \\
Accepted Jul 05, 2019 \\
\hline
\end{tabular}

\section{Keyword:}

Worm level,

Pottery craftsman

\begin{abstract}
Worm infection is an infestation of one or more intestinal parasitic worms consisting of intestinal nematodes. Among intestinal nematodes there are a number of species which are transmitted through soil or commonly referred to as STH worms, namely Ascaris lumbricoides, Necator americanus, Trichuris trichuira and Ancylostoma duodenale. The purpose of this research was to find out the description of the level of soil transmitted helminth (STH) infection in pottery craftsmen in Banyumulek Village, West Lombok. This research method uses analytic observational method with cross-sectional approach, sampling technique using Non-random Purposive Sampling technique, and Analysis of the results of the study carried out descriptively. The number of samples in this study were 30 people. Of the 30 samples examined, 1 of them was positively infected with intestinal nematode worms with the discovery of worm eggs of Hookworm with a percentage of $3.33 \%$, whereas in other samples no intestinal or negative nematodes were found with a percentage of $96.66 \%$. With rates of infection including mild infections. So the conclusion is that STH worm eggs obtained in pottery stools are Hookworm with the level of helminthiasis infection included in the category of mild infection.
\end{abstract}

Copyright $\odot$ Jurnal Analis Poltekkes Kemenkes Mataram

\begin{abstract}
ABSTRAK
Infeksi cacing adalah sebagai infestasi satu atau lebih cacing parasit usus yang terdiri dari golongan nematoda usus. Diantara nematoda usus ada sejumlah spesies yang penularannya melalui tanah atau biasa disebut dengan cacing jenis STH yaitu Ascaris lumbricoides, Necator americanus, Trichuris trichuira dan Ancylostoma duodenale. Tujuan dalam penelitian ini adalah untuk mengetahui gambaran tingkat infeksi cacing soil transmitted helminth (STH) pada pengrajin gerabah di Desa Banyumulek Lombok Barat. Metode penelitian ini menggunakan metode observational analitik dengan pendekatan cross-sectional, teknik pengambilan sampel dengan cara teknik Non random Purposive Sampling,dan Analisis hasil penelitian dilakukan secara deskriptif. Jumlah Sampel dalam penelitian ini adalah 30 orang. Dari 30 sampel yang diperiksa di dapatkan 1 diantaranya positif terinfeksi kecacingan nematoda usus dengan ditemukannya telur cacing jenis Hookworm dengan persentase 3,33\% sedangkan pada sampel lainya tidak ditemukan adanya nematoda usus atau negatif dengan persentase 96,66\%. Dengan tingkat infeksi termasuk infeksi ringan. Jadi kesimpulannya adalah Telur cacing golongan STH yang didapatkan pada feses pengrajin gerabah adalah Hookworm dengan tingkat infeksi kecacingan termasuk dalam kategori infeksi ringan.
\end{abstract}

Kata Kunci : tingkat kecacingan, pengrajin gerabah

Copyright (C) Jurnal Analis Poltekkes Kemenkes Mataram

\section{Pendahuluan}

Infeksi cacingan menurut WHO (2011) adalah sebagai infestasi satu atau lebih cacing parasit usus yang terdiri dari golongan nematoda usus. Diantara nematoda usus ada sejumlah spesies yang penularannya melalui tanah atau biasa disebut dengan cacing jenis STH yaitu Ascaris lumbricoides, Necator americanus, 
Trichuris trichuira dan Ancylostoma duodenale (Zulkoni, 2011). Cacingan ini umumnya ditemukan di daerah tropis dan subtropis dan beriklim basah dimana hygiene dan sanitasinya buruk. Penyakit ini merupakan penyakit infeksi paling umum menyerang kelompok masyarakat ekonomi lemah dan ditemukan pada berbagai golongan usia (WHO, 2011).

Berdasarkan data dari World Health Organization (WHO) pada tahun 2015, menyebutkan bahwa lebih dari 1,5 miliar orang atau $24 \%$ dari populasi Dunia terinfeksi oleh cacing yang ditularkan melalui tanah. Dimana lebih dari 270 juta anak usia pra-sekolah dan lebih dari 600 juta anak usia sekolah yang menderita infeksi (STH) dan membutuhkan perlakuan yang intensif. Penyakit cacingan yang ditularkan melalui tanah (Soil Transmitted Helminthiasis), masih menjadi masalah kesehatan masyarakat di negaranegara beriklim tropis dan sub tropis, termasuk Negara Indonesia (Siswa et al., 2017).

Faktor-faktor yang berpengaruh terhadap kejadian penyakit cacingan adalah faktor sosial ekonomi, satatus gizi, penataan kesehatan lingkungan, higenitas, sanitasi serta pendidikan dan perilaku individu serta faktor genetik (sorensen dkk,2012).

Kabupaten Lombok Barat sendiri, berdasarkan hasil survei Depkes pada tahun 2011, menunjukan bahwa prevalensi kecacingan di Kabupaten Lombok Barat mencapai angka 29,47\%. Angka ini termasuk tinggi dan menempati peringkat ke-5 dari hasil survei yang telah dilakukan pada beberapa kabupaten di Indonesia. Berdasarkan data hasil pemberian obat cacing yang diberikan kepada 10 Kabupaten/Kota di provinsi NTB (2014) menunjukkan bahwa sasaran pemberian obat cacing pada balita di Kabupaten Lombok Barat cukup tinggi jika dibandingkan dengan Kabupaten/Kota lainnya di provinsi NTB yaitu sekitar 70.246 balita.

Desa Banyumulek merupakan salah satu Desa dari 10 (Sepuluh) Desa yang ada di Kecamatan Kediri Lombok Barat. Desa Banyumulek memiliki luas : $243 \mathrm{Ha}$ atau 2,43 $\mathrm{km}^{2}$ yang terdiri dari 10 Dusun dan 42 Rukun Tangga (RT). Kerajinan gerabah tersebut diwarisi turun temurun oleh warga Banyumulek bermata pencarian sebagai pembuat Gerabah dan sampai saat ini sebagian dari warga Desa Banyumulek masih bekerja sebagai pengrajin gerabah maupun menjual gerabah sebagai mata pencariannya.

Penelitian ini bertujuan untuk mengidentifikasi cacing Soil Transmitted Helminth (STH) pada pengrajin Gerabah di Desa Banyumulek dan menganalisa tingkat infeksi cacing (STH) pada pengrajin Gerabah di Desa Banyumulek Lombok Barat.

\section{Metode Penelitian}

Penelitian ini menggunakan metode observasional analitik yaitu dilakukan sekumpulan objek yang biasanya bertujuan untuk melihat gambaran fenomena (termasuk kesehatan) yang terjadi di dalam populasi tertentu dengan menggunakan desain penelitian cross sectional yaitu penelitian yang dilakukan secara cross sectional (satu titik waktu tertentu) pada populasi atau penelitian pada sampel yang merupakan dari populasi (Swarjana, 2015). Sampel adalah bagian dari populasi yang diambil sebanyak 30 sampel dari pengrajin gerabah yang bertempat tinggal di Desa Banyumulek Lombok Barat.

Teknik pengambilan sampel dari penelitian ini adalah dengan teknik Non random Purposive Sampling adalah pengambilan sampel didasarkan sesuai dengan keinginan peneliti atau menggunakan pertimbangan tertentu (Notoatmodjo, 2014). Adapun sampel yang digunakan dalam penelitian, yaitu memenuhi kriteria inklusi dan ekslusi, dimana Merupakan syarat yang harus dipenuhi oleh responden untuk menjadi sampel yang akan di lakukan dalam penelitian ini, kriteria inklusinya adalah responden yang tidak menggunakan alat pelindung diri (APD) (sarung tangan, Sandal, Masker) pada saat bekerja, bersedia untuk menjadi responden dan responden berusia dewasa.

Data yang diperoleh dianalisis secara deskriftif dengan menghitung presentase tingkat kontaminasi infeksi kecacingan telur cacing Ascaris lumbricoides, Trichuris trichiura dan Hookworm pada pengrajin gerabah di Desa Banyumulek Lombok Barat.

\section{Hasil Penelitian dan Pembahasan}

Hasil pemeriksaan serta persentase infeksi kecacingan nematoda usus yang ditularkan melalui tanah Soil transmitted Helminthes (STH) terhadap sampel feses pengrajin gerabah di Desa Banyumulek Lombok Barat. 
Tabel 4.1. Hasil pemeriksaan dan persentase infeksi kecacingan nematoda usus pada pengrajin gerabah di Desa Banyumulek Lombok Barat.

\begin{tabular}{|c|c|c|c|c|}
\hline No & $\begin{array}{c}\text { Hasil } \\
\text { Pemeri } \\
\text { ksaan }\end{array}$ & $\begin{array}{c}\text { Jum } \\
\text { lah }\end{array}$ & Persentase & Keterangan \\
\hline 1 & Positif & 1 & $3,33 \%$ & Hookworm \\
\hline 2 & Negatif & 29 & $96,66 \%$ & \\
\hline & Jumlah & 30 & $100 \%$ & \\
\hline
\end{tabular}

Tabel 4.1. Pada hasil pemeriksaan telur cacig usus golongan STH pada feses pengrajin gearabah yang bertempat tinggal di Desa Banyumulek Lombok barat. Menunjukkan hasil pemeriksaan infeksi kecacingan pada pengrajin gerabah yang menunjukkan 1 pengrajin gerabah positif terinfeksi kecacingan nematoda usus dengan ditemukannya telur cacing jenis Hookworm dengan persentase 3,33\% sedangkan pada sampel lainya tidak ditemukan adanya nematoda usus atau negatif dengan persentase 96,66\%. Dari 30 sampel yang diperiksa di dapatkan 1 diantaranya positif kecacingan.

Tabel 4.2 Derajat tinkat infeksi kecacingan pada feses pengrajin gerabah yang bertempat tinggal di Desa Banyumulek Lombok Barat.

\begin{tabular}{|c|c|c|r|l|}
\hline $\begin{array}{c}\text { No } \\
\text { sam } \\
\text { pel }\end{array}$ & $\begin{array}{c}\text { Jenis Telur } \\
\text { Cacing }\end{array}$ & $\begin{array}{c}\text { Jum } \\
\text { lah } \\
(\mathrm{N})\end{array}$ & Derajat Infeksi & $\begin{array}{l}\text { Keteran } \\
\text { gan }\end{array}$ \\
\hline A14 & Hookworm & 50 & Gram feses $=\frac{\mathrm{N}}{40} \times 1000$ & Ringan \\
& & $\frac{50}{40} \times 1000$ & \\
& & 1.250 telur/gram & \\
\hline
\end{tabular}

Tabel 4.2 Didapatkan hasil pemeriksaan pada sampel no. A14 50 butir telur (sebesar 1.250 telur dalam 1 gram feses). Dari hasil sampel yang positif kecacingan menunjukkan bahwa tingkat infeksi kecacingan yang dialami oleh pengrajin gerabah yang bertempat timnggal di Desa Banyumulek Lombok Barat termasuk infeksi ringan.

Berdasarkan jumlah telur cacing Hookworm yang ditemukan di feses pengrajin gerabah dengan menggunakan metode kato-katz adalah sebanyak 50 telur dalam $40 \mathrm{mg}$ (berat tinja sesuai ukuran lubang karton). Hasil perhitungan tingkat infeksi telur cacing usus golongan STH menggunakan rumus Departeman Kesehatan RI, 2006.

\section{Kesimpulan}

Hasil pemeriksaan sampel feses pada pengrajin gerabah yang bertempat tinggal di Desa Banyumulek Lomboak Barat dari 30 sampel yang telah di periksa di dapatkan 1 diantaranta positif kecacingan dengan ditemukan telur cacing usus jenis Hookworm dengan tingkat infeksi kecacingan masih termasuk dalam kategori infeksi ringan.

\section{Daftar Pustaka}

1. Afifi, F., Triani, E., Primayanti, I., \& Gizi, S. (n.d.). Hubungan antara kecacingan dengan status gizi Lombok.

2. Antara, H., Kecacingan, I., Anemia, D., Status, D. A. N., Pada, G., \& Kuala, K. B. (2011). Oleh : Sri Yani Wijianingsih NIM : 08S1AJ0014 Program Studi S1 Gizi Sekolah Tinggi Ilmu Kesehatan Husada Borneo Banjarbaru Skripsi Sri Yani Wijianingsih Husada Borneo Banjarbaru, 1-96.

3. Di, A., Pasirlangu, S. D. N., Andaruni, A., Fatimah, S., \& Simangunsong, B. (2010). Gambaran faktor-faktor penyebab infeksi cacingan pada anak di sdn 01 pasirlangu cisarua, 1-15. Fakultas Kedokteran Universitas Andalas. (2015), 1-7.

4. Depkes RI. Keputusan Menteri Kesehatan Nomor: 424/MENKES/SK/VI/2006 mengenai pedoman pengendalian cacingan. URL: http.//www.depkes.go.id/downloads/kepmenkes.

5. dr. Desak Putu Yuli Kurniati. (2014). Hubungan kejadian kecacingan dengan status gizi anak SD serta pengobatan kecacingan pada anak SD dI DESA Jagapati, Kotamadya Denpasar -BALI (0029098010). 
6. Indonesia, U., Widyasari, A., Kedokteran, F., Studi, P., \& Umum, K. (2012). Universitas indonesia.

7. Ismid, I.S., Winita, R., Sutanto, I., Zulhasril. Sjarifuddin, P.k. (2000). Penuntun Praktikum Parasitologi Kedokteran. Fakultas Kedokteran Universitas Indonesia. Jakarta.

8. Irianto, K. 2013. Medis Parasitologi (Medical Parasitology). Alfabeta CV. Hlm. 232-237. Bandung.

9. Kerja, W., Tamangapa, P., \& Makassar, A. (2013). Hubungan personal hygiene dengan cacingan pada anak di wilayah kerja puskesmas tamangapa antang Makassar.

10. Luis, R., \& Tuda, J. S. B. (2016). Kecacingan usus pada anak sekolah dasar di Tanawangko Kecamatan Tombariri Kabupaten Minahasa, 4, 2-5.

11. Ni Wayan Sri Krisna Yanti. (2018) Identifikasi Telur cacing Soil Transmitted Helminth Pada Potongan kuku Tangan Pengrajin Gerabah Di Sentral Kerajinan Gerabah Kelurahan Kapal Kecamatan Mengwi Kabupaten Bandung.

12. Notoatmodjo, S. (2014) Metodolodi Penelitian Kesehatan. Jakarta : Rineka Cipta.

13. Prasetyo Yudha,. (2016). Hubungan faktor sosio-ekonomi dan tingkat pengetahuan orang tua dengan kejadian infeksi soil transmited helminth (STH) dan pemetaan tempat tinggal siswa terinfeksi STH pada siswa SDN 1 krawangsari natar.

14. Proksalia, A. Y. U. (2016). Prevalensi infeksi kecacingan pada anak sekolah dasar di desa pengobatan filariasis dan non pengobatan filariasis.

15. Setyowatiningsih, L., \& Surati, S. (2017). Jurnal Riset Kesehatan, 6(1), 40-44.

16. Siswa, P., Iv, K., Sd, D. A. N. V, Mawasangka, N., Buton, K., \& Tahun, T. (2017). Pengaruh penyuluhan dengan metode permainan edukatif sukata terhadap pengetahuan, sikap dan tindakan tentang pencegahan penyakit cacingan pada siswa kelas iv dan $\mathrm{v}$ sd negeri 1 mawasangka kabupaten buton tengah tahun 2016, 2(5), 1-10.

17. Sujatmiko. 2005. 100\% Pengrajin Gerabah di Lombok Cacingan. Available from : http//: www.tempointeraktif.com. Acessed: January, 272010.

18. Swarjana, I. (2015) Metode Penelitian Kesehatan. Edisi Revisi. Yogyakarta : ANDI.

19. Tri, A., Amaliah, R., \& Indo-, D. (2016). Distribusi Spasial Kasus Kecacingan ( Ascaris lumbricoides ) Terhadap Personal Higiene Anak Balita di Pulau Kodingareng Kecamatan Ujung Tanah Kota Makassar Tahun 2016.

20. Zulkoni.A (2011), Parasitologi , Nuha Medika, Yogyakarta. 